\title{
The Ability Of Prospective Teacher of Elemetary School to Solve The Problems Related to Water, Air, and Soil Themes
}

\author{
Atep Sujana \\ Indonesia University of Education \\ E-mail: atepsujana261272@gmail.com \\ Anna Permanasari \\ Indonesia University of Education \\ Co-author: anna_permanasai@upi.edu
}

\author{
Wahyu Sopandi \\ Indonesia University of Education \\ Ahmad Mudzakir \\ Indonesia University of Education
}

\begin{abstract}
This study aims to improve the ability of Prospective Teacher of Elementary School (PTES) in solving problems related to water, air, and soil themes. Learning was designed in several themes and was implemented by using problem-based learning (PBL) model. The effectiveness of the model was then studied on using experimental research with pretest-post-test control group design. Subjects in this study were thirty-two PTES students who attended the basic concepts of chemistry course. The instruments consists of test (multiple choices test completed with reasons), interview, and questionnaire. Questionnaire and interview were used to explore other things that could not be revealed from the test. Data processing was done on using quantitative and qualitative ways. Quantitative data processing was performed by using simple statistics through the SPSS-16 program. Qualitative data processing was done descriptively. The results show that, in general, the skills of PTES students on solving problems significantly increased after the implementation of PBL models. Student show very good responses to the PBL activities. The nurturing effect of the leaning process can be explained based on students' perception. They said that the learning model could be adopted and highly applied in elementary school student's levels.
\end{abstract}

Keywords-Prospective Teacher of Elementary School, Problem Solving, Problem-Based Learning, Lectures of Basic Concepts of Chemistry.

\section{INTRODUCTION}

Current external challenges faced by nations of the world requires a transformation in education. [1] This transformation can be done through improving the quality of learning. Learning is an educational process that provides opportunities for learners to develop their potential to build an ability that is increasingly rising in terms of attitudes, knowledge, and skills. These are needed for life, society, and nation as well as contribute to the welfare of mankind. [2] Learning should be directed to empower all potential of the learners, so as to assist in developing their intellectual ability, social skills, personal ability and other abilities.

To be able to develop all potential of the learners optimally, it is necessary to have professional teachers who have high competence to explore the ability of their students. In terms of education in elementary school, every teacher and prospective teacher should be equipped with a wide range of abilities that can be applied when implementing the learning in school and have academic qualifications that are appropriate with their level of authority. Therefore, every elementary school teacher must have a minimum education qualification of a Diploma (DIV) or Bachelor (S1) in the field of elementary school teacher education or psychology from an accredited institution. [3]

One way to equip the ability of teachers and prospective elementary school teachers in exploring all the potential of learners is through learning the basic concepts of chemistry. On learning this, all students are learned various basic concepts of chemistry. The skills are required to implement these concepts to be taught in elementary school. One of the skills is problem-solving skill.

Students' problem-solving skills need to be trained in order to make the students get accustomed to resolve the problems they face in their road to success. [4] Problem solving is the ability of a person to be directly involved in cognitive processes in understanding and addressing problems in real-life situations. [5] Some of the problemsolving indicator that can be provided to students are to understand the problem, gather information on ways of solving the problem, as well as to prepare reports and evaluation

Problem-solving based learning (PSBL) is an active learning that provides students with an opportunity to take decisions on the problems being faced. Through this learning model, students become active learners. They try to find the needed information, develop high-level thinking skills, and develop the right way to solve the problems.

PSBL is very important for students, as it can develop the students' scientific skills, from observation, measurement, determination of hypotheses, problem solving planning, problem solving testing, and communicating the results of problem solving. PSBL is one of the recommended methods in teaching chemistry, because it can 
help students learn chemistry more effective. [6] Through a problem-solving approach, students can learn in defining problems, collecting information related to problem-solving, as well as examining and evaluating alternative solutions to the problems.

As one of the learning models problem-based learning (PBL) aims to inculcate a culture of learning by providing basic knowledge and skills to solve problems. [7] Another goal of PBL is that students can learn based on the problems faced, to explain the specific subject matter better. [8] The main focus of PBL is a learning experience that is organized around the investigation, explanation and problem solving. [9] PBL can change students' habits from recipient of information into information seekers so as to facilitate the students learn new knowledge by finding a way to solve the problem. When students learn through PBL, teachers encourage students to explore, find solutions, collaborate with friends, trying new ideas, improve the ideas, as well as presenting the best solution. [10] This is very important because all students have to make decisions or solve problems of socio-scientific based on knowledge. [11] In PBL, students can work in small groups, as well as learn what is required to solve the problems encountered in the subject of basic concepts of chemistry, related to the theme of water, air, and soil.

Solving problems related to the basic concepts of chemistry are very important to everyone, because the chemistry is very important in life. This is because all aspects of life such as water, air, soil, food, clothing, medicine, housing, vehicles, and so on related to chemistry. Similarly, almost all human needs such as televisions, computers, photocopying machines, among others, come from the advancement of chemistry. [12] Therefore, studying chemistry is a powerful motivation in developing the technology that can make individual life better. [13] Through the chemistry learning, it is expected that individuals' life will be easier, cheaper, and better.

Given the importance of chemistry for life, PGSD students must acquire a solid understanding on matters relating to chemistry, because they will teach those matters in elementary schools. Though the chemistry is not specifically taught in elementary schools, but many of the basic concepts of chemistry must be mastered by elementary school students embedded in science subjects. [14]

Chemistry subjects taught to prospective elementary school teacher must be closely related to their daily lives. Learning context indicates that students' learning results will increase if the assigned materials are relevant to their lives. [15]

Therefore, learning materials are organized in certain themes include water, air, and soil. Water, air, and soil are the most important components of life. Water $\left(\mathrm{H}_{2} \mathrm{O}\right)$ is the largest component in living things, including humans. The water that makes up the human body organs vary as the brain reaches $75 \%$, lung $90 \%$, and the bone is $22 \%$. [16] If human body lacks of water only slightly, the organs of the human body will be disrupted. Water used by human must be safe for health, and do not contain harmful bacteria for life. Another important role of water is as a solvent that can dissolve many substances. Water's ability to dissolve various substances can also be detrimental, because it may cause pollution. Water pollution is one of the problems that must be solved by applying the science of chemistry.

In addition, air and soil are also important components in life. The air is needed for breathing, as well as other activities. At the time of breathing humans inhale oxygen gas $\left(\mathrm{O}_{2}\right)$ and emit carbon dioxide $\left(\mathrm{CO}_{2}\right)$. Similarly, soil is needed by living organisms for various activities.

\section{RESEARCH METHODOLOGY}

The study was conducted to improve students' ability to solve the problems related to the theme of water, air, and soil. Research subjects were students of an elementary school teacher education in one of the universities in West Java, Indonesia, in level of S-1 (32 students as an experiment group and 32 student as control group). Intake of research subjects was based on the consideration that the students of elementary school teacher education learn some basic concepts of chemistry in courses related to science, but not all of them have science backgrounds. Therefore, they must be equipped with a variety of skills needed when carrying out the task of teaching in schools such as the ability to solve problems.

The method used is experimental research with pretest-post-test control group design. This design is the most commonly used experimental design due to its recognized strength in controlling threats to internal validity. [17] Research subjects were given two measurements, before and after treatment to see the effect of this treatment on the measurement results. [18]

$\begin{array}{lllll}\text { Experimental: } & R & O 1 & X & O 2 \\ \text { Control: } & R & O 3 & & O 4\end{array}$

Note: $\mathrm{R}=$ Randomization, $\mathrm{O}=$ Testing, $\mathrm{X}=$ Treatment.

To determine the achievement of the research objectives, research instrument consisting of test questions, interviews, questionnaires, and observation report of the problems found in everyday life related to the theme of water, air, and soil were used. The test items used were 30 multiple-choice questions that come with reason or other information to reinforce the answers given. The test questions cover all aspects of learning, covering aspects of the content, context, process, and scientific attitude. In practice, all research subjects were given a set of chemistry literacy problem, to be solved in 120 minutes. Their seats were also designed in such way and are carefully supervised, so that they would not be able to cooperate in answering the questions.

Besides the test, an interview was also conducted to reinforce the answer that have not been revealed yet. The interview was conducted in the form of open-ended interview. This interview allows the interviewer to search for and identify any responses given by the questions that 
have been arranged. [19] In this interview, questions and the order of the words in question were determined in advance, so that all the interviewer were given the same basic questions to be developed further. [20]

In addition to test and interview, a questionnaire was also used. The questionnaire used is a direct questionnaire, where respondents answered directly and reassembled directly after filling. This questionnaire was used among others to know the background of the student, the student motivation in following the basic concepts of chemistry courses, student interest, student needs, the suitability between the material provided to the needs at work, as well as students' feedback regarding the implementation of learning. In addition, an assessment was conducted on the results of observations in order to determine the ability of students in solving problems in life that are related to the theme of water, air, and soil.

\section{RESEARCH RESULTS AND DISCUSSIONS}

As it was studied before, the PBL was implemented in experiment group, whether the controlled group was threated under conventional learning (conceptual approach with discussion session). Both of group did the pre and posttest with the same test, show that in general students learning in experiment groups experience increased ability in solving the existing problems related to the theme of water, air, and soil in the course of the basic concepts of chemistry. The trend of N-Gain increasing of both group is shown by Table 1 .

Table 1. N-Gain Increasing of Both Group

\begin{tabular}{|c|c|c|c|c|c|c|c|c|c|c|}
\hline \multirow[b]{2}{*}{ Group } & \multicolumn{4}{|c|}{ Average pretest } & \multicolumn{4}{|c|}{ Average posttest } & \multirow{2}{*}{$\begin{array}{l}\text { Average } \\
\text { N-Gain }\end{array}$} & \multirow{2}{*}{$\begin{array}{c}\% \\
\text { N-Gain }\end{array}$} \\
\hline & Water & Air & Soil & $\begin{array}{l}\text { Ave } \\
\text { rage }\end{array}$ & Water & Air & Soil & $\begin{array}{l}\text { Ave } \\
\text { rage }\end{array}$ & & \\
\hline Experiment & 63.24 & 64.54 & 65.85 & 64.54 & 78.13 & 84.29 & 85.73 & 82.72 & 18.18 & 0.51 \\
\hline Control & 65.37 & 67.15 & 68.94 & 67.15 & 75.00 & 79.97 & 82.77 & 74.25 & 7.10 & 0.22 \\
\hline
\end{tabular}

The average of pretest shows that the students from both group were able to answer the problem-based questions despite the moderate category. This is most likely because they have prior knowledge regarding the materials to be taught. But their responses were not systematic due to the fact that they have not learned about the flow of knowledge.
In students' ability to solve problem, related to the theme of water, air, and soil the posttest from both of group after learning shows significant increase. Problem solving skills of both of group are enhancing in high category.

Table 2. Normality Test Result One-Sample Kolmogorov-Smirnov Test

\begin{tabular}{|c|c|c|c|c|c|c|c|c|c|c|c|c|c|}
\hline & & $\begin{array}{c}\text { Pre } \\
\text { test } \\
\text { water } \\
\exp \end{array}$ & $\begin{array}{c}\text { Post } \\
\text { test } \\
\text { water } \\
\exp \end{array}$ & $\begin{array}{l}\text { pretest } \\
\text { air exp }\end{array}$ & $\begin{array}{l}\text { Post } \\
\text { test } \\
\text { air } \\
\text { exp }\end{array}$ & $\begin{array}{l}\text { pretest } \\
\text { soil } \\
\exp \end{array}$ & $\begin{array}{l}\text { Post } \\
\text { test } \\
\text { soil } \\
\text { exp }\end{array}$ & $\begin{array}{l}\text { pretest } \\
\text { water } \\
\text { contr }\end{array}$ & $\begin{array}{l}\text { posttest } \\
\text { water } \\
\text { contr }\end{array}$ & $\begin{array}{l}\text { pretest } \\
\text { air contr }\end{array}$ & $\begin{array}{l}\text { Post } \\
\text { test air } \\
\text { contr }\end{array}$ & $\begin{array}{l}\text { pretest } \\
\text { soil } \\
\text { contr }\end{array}$ & $\begin{array}{l}\text { Post test } \\
\text { soil contr }\end{array}$ \\
\hline \multicolumn{2}{|l|}{$\mathrm{N}$} & 32 & 32 & 32 & 32 & 32 & 32 & 32 & 32 & 32 & 32 & 32 & 32 \\
\hline $\begin{array}{l}\text { Normal } \\
\text { Parameters } \\
\text { a,b }\end{array}$ & Mean & $\begin{array}{r}63,23 \\
78\end{array}$ & $\begin{array}{r}78,125 \\
3\end{array}$ & $\begin{array}{r}64,540 \\
0\end{array}$ & $\begin{array}{r}84,2 \\
859\end{array}$ & $\begin{array}{r}65,849 \\
4\end{array}$ & $\begin{array}{r}85,733 \\
8\end{array}$ & $\begin{array}{r}65,365 \\
0\end{array}$ & 74,9994 & 67,1478 & $\begin{array}{r}79,966 \\
3\end{array}$ & $\begin{array}{r}68,942 \\
5\end{array}$ & 82,7669 \\
\hline \multirow{3}{*}{$\begin{array}{l}\text { Most } \\
\text { Extreme } \\
\text { Difference } \\
\text { s }\end{array}$} & Absolute &, 173 & , 194 &, 171 & , 159 & , 155 & ,143 &, 125 & , 185 & , 164 & ,164 & ,240 & ,161 \\
\hline & Positive & ,173 & ,114 & , 157 & , 153 & , 155 & ,143 &, 125 & , 185 & , 164 & ,164 & ,221 & ,161 \\
\hline & Negative &,- 115 &,- 194 &,- 171 & , $159^{-}$ &,- 088 &,- 079 &,- 083 &,- 125 &,- 148 &,- 154 &,- 240 &,- 106 \\
\hline \multicolumn{2}{|c|}{$\begin{array}{l}\text { Kolmogorov-Smirnov } \\
\text { Z } \\
\text { Asymp. Sig. (2-tailed) }\end{array}$} & ,976 & 1,100 & ,965 & ,900 & ,879 & ,811 & ,709 & 1,045 & ,929 & ,929 & 1,358 & ,913 \\
\hline
\end{tabular}

Based on Table 2, it is found that the p-value of each test variable> $0.025(\alpha / 2)$. Because of this normal distribution of data, t-test was conducted after wards. The complete t-test results is listed in the following Table 3 and 4. 
Table 3. T-Test Results Experiment Group Paired Samples Test

\begin{tabular}{|c|c|c|c|c|c|c|c|c|c|}
\hline & & \multicolumn{5}{|c|}{ Paired Differences } & \multirow{3}{*}{$\mathrm{t}$} & \multirow{3}{*}{$\mathrm{df}$} & \multirow{3}{*}{$\begin{array}{l}\text { Sig. (2- } \\
\text { tailed) }\end{array}$} \\
\hline & & \multirow[t]{2}{*}{ Mean } & \multirow{2}{*}{$\begin{array}{c}\text { Std. } \\
\text { Deviatio } \\
\text { n }\end{array}$} & \multirow{2}{*}{$\begin{array}{c}\text { Std. } \\
\text { Error } \\
\text { Mean }\end{array}$} & \multicolumn{2}{|c|}{$\begin{array}{l}\text { 95\% Confidence Interval of the } \\
\text { Difference }\end{array}$} & & & \\
\hline & & & & & Lower & Upper & & & \\
\hline Pair 1 & $\begin{array}{l}\text { pretest water exp - } \\
\text { posttest water exp }\end{array}$ & $-14,88750$ & 4,37954 &, 77420 & $-16,46649$ & $-13,30851$ & $-19,229$ & 31 & ,000 \\
\hline Pair 2 & $\begin{array}{l}\text { pretest air exp - } \\
\text { posttest air exp }\end{array}$ & $-19,74594$ & 3,27837 & ,57954 & $-20,92792$ & $-18,56396$ & $-34,072$ & 31 & ,000 \\
\hline Pair 3 & $\begin{array}{l}\text { pretest soil exp - } \\
\text { posttest soil exp }\end{array}$ & $-19,88437$ & 4,57791 & ,80927 & $-21,53489$ & $-18,23386$ & $-24,571$ & 31 & ,000 \\
\hline
\end{tabular}

Table 4. T-Test Results Control Group Paired Samples Test

\begin{tabular}{|c|c|c|c|c|c|c|c|c|c|}
\hline & & \multicolumn{5}{|c|}{ Paired Differences } & \multirow{3}{*}{$\mathrm{t}$} & \multirow{3}{*}{$\mathrm{df}$} & \multirow{3}{*}{$\begin{array}{l}\text { Sig. (2- } \\
\text { tailed) }\end{array}$} \\
\hline & & \multirow[t]{2}{*}{ Mean } & \multirow{2}{*}{$\begin{array}{c}\text { Std. } \\
\text { Deviatio } \\
n\end{array}$} & \multirow{2}{*}{$\begin{array}{c}\text { Std. } \\
\text { Error } \\
\text { Mean }\end{array}$} & \multicolumn{2}{|c|}{$\begin{array}{l}\text { 95\% Confidence Interval of the } \\
\text { Difference }\end{array}$} & & & \\
\hline & & & & & Lower & Upper & & & \\
\hline Pair 1 & $\begin{array}{l}\text { pretest water contr - } \\
\text { posttest water contr }\end{array}$ & $-9,63438$ & 2,99426 & ,52931 & $-10,71392$ & $-8,55483$ & $-18,202$ & 31 &, 000 \\
\hline Pair 2 & $\begin{array}{l}\text { pretest air contr - } \\
\text { posttest air contr }\end{array}$ & $-12,81844$ & 3,39947 & ,60095 & $-14,04408$ & $-11,59280$ & $-21,330$ & 31 & ,000 \\
\hline Pair 3 & $\begin{array}{l}\text { pretest soil contr - } \\
\text { posttest soil contr }\end{array}$ & $-13,82437$ & 4,67746 &, 82687 & $-15,51078$ & $-12,13797$ & $-16,719$ & 31 & ,000 \\
\hline
\end{tabular}

The data obtained indicates that the problem-based learning is helping students solve problems in life. Shows that there are significant differences in the value of pretest and posttest for the experimental and control groups. The students learn not only based on the theory that exist in textbooks alone, but also based on the problems found in real life situations. By the problems, the students learn the theory found in textbooks and aplied it in in real life. PBL is not designed to help teachers convey information to students in detail, but rather to help students develop thinking skills, problem-solving skills, as well as intellectual skills. [21] The teachers only responsible to facilitate the learning process, provide training to students in solving problems, as well as a guiding student to obtain relevant information. [22]

Improvement in learning outcomes occurs because students were directly involved during the learning. Students were actively involved in looking for problems, developing theory to solve the problem through reading literature or direct observation to the field, as well as finding alternatives to solve their problems. In other words, students have a big role in solving problems. Active learning can help students develop a sense of curiosity, a desire to apply their knowledge, develop skills in learning, as well as preparing themselves for the future. [23] Active learning also can provide a strong conceptual foundation in students and help them in solving the problems. [24] Through active learning, students are encouraged to learn more deeply about the problems faced and ways of solving these problems, so the ability of students will be increased. The students will also realize that they will have benefit from the results of reading and observation that they had done problems. They will come to class in a condition ready to learn, because they have obtained information from various sources.

Based on interviews and observations during the learning process, student success in solving the problems related to these themes occur because the learning model encourage them to be more active and creative in finding a variety of literature and other information based on the results of field observations to be solved together in the next step. This learning approach is found beneficial in enhancing the cooperation between students, resulting in the exchange of ideas between students with each other. Also, based on the report of their observations it is found that they carry out observations seriously to the problems that occur in the field, and seek information from the literature and the interviewee as a resource. They found some ways to overcome the existing problems related to the theme of water, air, and soil.

Although in general there the students' ability to solve problems, are increased but there are some students 
who are still not able to finish it well. Their weakness is primarily concerned with the use of chemistry concepts such as determination of the molecular formula, giving the name of the chemical compound, writing equation, determining the outcome of a chemical reaction, and the concentration of the solution. Based on the interviews and questionnaires given to students, their inability to solve the problem are because their educational background is not from science program. For some of them, that was their first time experience to learn about chemistry. Based on the results of questionnaires, more than a half of the students don't have science education background.

\section{CONCLUSION}

Based on the research, it is concluded that in general the students' ability to solve problems before and after learning are significantly different for each theme. Problembased learning can help students solve problems related to the theme of water, air, and soil. Based on statistical test it is known that there are significant differences between the results of pre-tests and post-test for each theme. The result of reinforced the conclusion interviews and observations during the learning process. Through the learning, students can determine the problem, look for alternatives that are considered appropriate to solve the problem, and propose ways to overcome the problems.

PBL can be used by teachers in implementing the learning in the classroom, both to the university students and school students. In other words, the learning model can be implemented in schools, including elementary schools. In practice, this learning model can be done in groups design. To achieve more effective learning and encourage student collaboration with other friends, it is recommended to implement the model in small groups.

\section{REFERENCES}

[1] Peraturan Menteri Pendidikan Dan Kebudayaan Nomor 67 Tahun 2013 Tentang Kerangka Dasar Dan Struktur Kurikulum Sekolah Dasar/Madrasah Ibtidaiyah.

[2] Peraturan Menteri Pendidikan Dan Kebudayaan Republik Indonesia Nomor 81a Tahun 2013 Tentang Implementasi Kurikulum Pedoman Umum Pembelajaran.

[3] Peraturan Menteri Pendidikan Nasional Republik Indonesia Nomor 16 Tahun 2007 Tentang Standar Kualifikasi Akademik Dan Kompetensi Guru

[4] Mustafa Dogru. (2008). The Application of Problem Solving Method on Science Teacher Trainees on the Solution of the Environmental Problems. Journal of Environmental \& Science Education, 3 (1), 918

[5] PISA OECD. (2012). Results: Creative Problem Solving StudentS' SkillS in Tackling Real-Life Problems (Volume V).

[6] Fatoke, A.O, Ogunlade, T.O, and Ibidiran, V.O. (2013). The Effects of Problem-Solving Instructional Strategy and Numerical Ability on
Students' Learning Outcomes. The International Journal of Engineering And Science (IJES), Volume 2, Issue 10, Pages 97-102.

[7] Redshaw, Clare H and Frampton, Ian. (2014). Optimising interdisciplinary problem-based learning in postgraduate environmental and science education: Recommendations from a case study. International Journal of Environmental \& Science Education, 9, 97 110.

[8] Orhan Akınoğlu and Ruhan Özkardeş Tandoğan. (2007). The Effects of Problem-Based Active Learning in Science Education on Students' Academic Achievement, Attitude and Concept Learning. Eurasia Journal of Mathematics, Science \& Technology Education, 3(1),71-8.

[9] Cindy E. and Hmelo-Silver. (2004). Problem-Based Learning: What and How Do Students Learn? Journal Educational Psychology Review, Vol. 16, No. 3 .

[10] Sungura, Semra and Tekkay, Ceren. (2010). Effects of ProblemBased Learning and Traditional Instruction on Self-Regulated Learning. The Journal of Educational Research, 99: 5, 307 320.07 .

[11] Illingworth, Sarah; Burke, Karen da Silva, and Amy Butler. (2012). Investigations of Socio-Biological Literacy of Science and NonScience Students. International Journal of Innovation in Science and Mathematics Education, 20(2), 55-67.

[12] Goldberg, David E. (2007). Fundamentals of Chemistry, Fifth Edition. The McGraw-Hill Companies,

[13] Glenn V. Lo and Michael A. Janusa. (2010). Chemistry the Core Concepts. North Carolina:Kona Publishing and Media Group

[14] Trefil, James and Hazen, Robert. (2010). Sciences an Integrated Approach. Sixth edition. Hoboken: John Wiley \& Sons.

[15] Karyne C.S. Anga, David van Reyk. (2013). Teach Me Chemistry Like a Ladder and Make it Real' - Barriers and Motivations Students Face in Learning Chemistry for Bioscience. International Journal of Innovation in Science and Mathematics Education, 21(2), pages 1-12.

[16] Eubanks, Lucy Pryde Et all. (2009). Chemistry In Context: Applying Chemistry To Society, Sixth Edition. New York: McGraw-Hill Companies, Inc.

[17] Yair Levy and Timothy J. Ellis. (2011). A Guide for Novice Researchers on Experimental and Quasi-Experimental Studies in Information Systems Research. Interdisciplinary Journal of Information, Knowledge, and Management Volume 6, 151- 161

[18] Ali, Mohamad. (2013). Penelitian Kependidikan Prosedur dan Strategi. Bandung: Angkasa.

[19] Creswell, John W. (2012). Planning, Conducting, And Evaluating Quantitative And Qualitative Research, Fourth Edition. Boston: Pearson Education, Inc.

[20] Cohen, Louis. Manion, Lawrence and Morrison, Keith. (2007). Research Methods in Education Sixth edition. New York: Routledge Taylor \& Francis Group

[21] Arends, Richard I. (2007). Learning to Teach. Seventh Eddition. New York. McGraw Hill.

[22] Tan, Oong-Seng. (2003). Problem-Based Learning Innovation Using Problems to Power Learning in the 21st Century. Singapore: Cengage Learning

[23] Meryem Nur Aydede and Fatih Matyar. (2009). The Effect of Active Learning Approach in Science Teaching on Cognitive Level of Student Achievement. Journal of TURKISH SCIENCE EDUCATION Volume 6, Issue 1.

[24] David E. Meltzer and Ronald K. Thornton. (2011). Active-Learning Instruction in Physics. Departments of Physics and Education, Center for Science and Mathematics Teaching, Tufts University. tersedia http://www.bu.edu/hps-scied/files/2012/10/Meltzer-HPSActive-Learning-Instruction-in-Physics.pdf 